\title{
A Red Fluorescent Protein-Based Probe for Detection of Intracellular Reactive Sulfane Sulfur
}

\author{
Zimai Li ${ }^{1}$, Qingda Wang ${ }^{1}$, Yongzhen Xia ${ }^{1} \mathbb{C}$, Luying Xun ${ }^{1,2}{ }^{\mathbb{C}}$ and Huaiwei Liu ${ }^{1, *(D)}$ \\ 1 State Key Laboratory of Microbial Technology, Shandong University, Qingdao 266237, China; \\ lizimai@mail.sdu.edu.cn (Z.L.); wangqingda@mail.sdu.edu.cn (Q.W.); xiayongzhen2002@sdu.edu.cn (Y.X.); \\ luying_xun@wsu.edu (L.X.) \\ 2 School of Molecular Biosciences, Washington State University, Pullman, WA 99164-7520, USA \\ * Correspondence: liuhuaiwei@sdu.edu.cn; Tel.: +86-532-5863-1572
}

Received: 7 August 2020; Accepted: 9 October 2020; Published: 13 October 2020

check for updates

\begin{abstract}
Reactive sulfane sulfur, including persulfide and polysulfide, is a type of regular cellular component, playing an antioxidant role. Its function may be organelle-dependent; however, the shortage of probes for detecting organellar reactive sulfane sulfur has hindered further investigation. Herein, we reported a red fluorescent protein (mCherry)-based probe for specifically detecting intracellular reactive sulfane sulfur. By mutating two amino acid residues of mCherry (A150 and S151) to cysteine residues, we constructed a mCherry mutant, which reacted with reactive sulfane sulfur to form an intramolecular $-S_{n}-$ bond $(n \geq 3)$. The bond largely decreased the intensity of $610 \mathrm{~nm}$ emission (excitation at $587 \mathrm{~nm}$ ) and slightly increased the intensity of $466 \mathrm{~nm}$ emission (excitation at $406 \mathrm{~nm}$ ). The $466 / 610 \mathrm{~nm}$ emission ratio was used to indicate the relative abundance of reactive sulfane sulfur. We then expressed this mutant in the cytoplasm and mitochondria of Saccharomyces cerevisiae. The $466 / 610 \mathrm{~nm}$ emission ratio revealed that mitochondria had a higher level of reactive sulfane sulfur than cytoplasm. Thus, the mCherry mutant can be used as a specific probe for detecting reactive sulfane sulfur in vivo.
\end{abstract}

Keywords: sulfane sulfur; antioxidation; mCherry; mitochondria; Saccharomyces cerevisiae

\section{Introduction}

Sulfane sulfur, including persulfide and polysulfide, is commonly present in both eukaryotic and prokaryotic cells [1]. Increasing studies have demonstrated that it has important physiological functions, including antioxidation, anti-inflammation, angiogenesis, and cell signaling [2-6]. However, the mechanisms underpinning its functions are still largely unknown. Cellular sulfane sulfur exists as hydrogen polysulfide $\left(\mathrm{HS}_{\mathrm{n}} \mathrm{H}, n \geq 2\right)$, organopolysulfide $\left(\mathrm{RS}_{n} \mathrm{H}, n \geq 2\right)$, and dialkyl polysulfide $\left(\mathrm{RS}_{\mathrm{n}} \mathrm{R}\right.$, $n \geq 3)$. They come in different reactivities with a rough order of $\mathrm{HS}_{n} \mathrm{H}>\mathrm{RS}_{n} \mathrm{H}>\mathrm{RS}_{n} \mathrm{R}[7,8] . \mathrm{HS}_{n} \mathrm{H}$ and $\mathrm{RS}_{\mathrm{n}} \mathrm{H}$ have both electrophilic and nucleophilic properties, and vividly react with reactive oxygen species (ROS), reactive nitrogen species (RNS), and signaling molecules at physiological pH (7.0 7.6). Therefore, they are usually referred to as reactive sulfane sulfur, which actually functions in biological systems. In contrast, $\mathrm{RS}_{\mathrm{n}} \mathrm{R}$ is relatively inert at physiological $\mathrm{pH}$, which may work as a reservoir of cellular sulfane sulfur [9-12].

The distribution of cellular sulfane sulfur shows heterogeneity at subcellular levels in eukaryotic cells, the peroxisomes and mitochondria are reported to have more reactive sulfane sulfur $\left(\mathrm{HS}_{\mathrm{n}} \mathrm{H}\right.$ and $\mathrm{GS}_{\mathrm{n}} \mathrm{H}$ ) than the cytoplasm of Saccharomyces cerevisiae [13]. Both organelles perform important roles in ROS homeostasis maintenance $[14,15]$. The heterogeneity suggests that reactive sulfane sulfur may function differently in each subcellular organelle. A recent research revealed that cysteine persulfide (Cys-SSH), which is produced by cysteinyl-tRNA synthetase 2 (CRS2) in mammalian mitochondria, 
is involved in mitochondria biogenesis and bioenergenesis [16]. Apart from this finding, little is known about the organellar sulfane sulfur. The shortage of specific methods for its dynamical detection has seriously hindered further investigation.

To address this challenge, we recently developed a green fluorescent protein (GFP)-based reactive sulfane sulfur detection probe, psGFP1.1, which reacts with hydrogen polysulfide and alters its fluorescence [13]. On the other hand, many widely used cell dyes and probes are based on the green range of fluorescence, and hence the GFP probe cannot be used simultaneously with them. In addition, peptone, yeast extract, and metal irons also have fluorescence in the green wavelength range. Some intracellular metabolites, such as flavin mononucleotide $\left(\mathrm{FMN}, \lambda_{\mathrm{em}, \max }=525 \mathrm{~nm}\right.$ and $\lambda_{\text {ex,max }}=450 \mathrm{~nm}$ ), can disturb the detection as well [17]. Therefore, the application of psGFP1.1 is limited in certain circumstances. To expand the toolbox of the fluorescence protein-based sulfane sulfur detection probe, we herein developed the red fluorescent protein-based probe, psRFP. We expressed this probe in the cytoplasm and mitochondria of yeast cells, demonstrating that it is a useful tool for studying intracellular sulfane sulfur at a subcellular level. Together with psGFP1.1, it will contribute to the study of cellular sulfane sulfur.

\section{Materials and Methods}

\subsection{Strains, Plasmids, and Compounds}

Escherichia coli DH5 $\alpha$ was used for plasmid construction. E. coli BL21(DE3) and S. cerevisiae BY4742 were used for protein expression. E. coli strains were grown in lysogeny broth (LB) medium. Kanamycin $(50 \mu \mathrm{g} / \mathrm{mL})$ was added when required. S. cerevisiae BY4742 was grown in SD-ura' medium (synthetic defined minimal medium without uracil) [18]. Dithiothreitol (DTT), L-cystine, and L-cysteine hydrochloride monohydrate were purchased from BBI life sciences (Shanghai, China) Company. Trans-4,5-dihydroxy-1,2-dithiane (Oxidized DTT), sodium thiosulfate pentahydrate $\left(\mathrm{Na}_{2} \mathrm{~S}_{2} \mathrm{O}_{3}\right)$, sodium sulfite $\left(\mathrm{Na}_{2} \mathrm{SO}_{3}\right)$, Isopropyl $\beta$-D-1-thiogalactopyranoside (IPTG), flavin mononucleotide (FMN), and reduced glutathione (GSH) were purchased from Sigma-Aldrich (Shanghai, China). $\mathrm{HS}_{\mathrm{n}} \mathrm{H}$ and GSSH (glutathione persulfide) were prepared and quantified by following reported protocols $[19,20]$.

\subsection{Protein Mutation, Expression, and Purification}

The gene encoding mCherry was ligated into the plasmid pET30a with a C-terminal His-tag. Amino acid mutations were introduced by a modified QuikChange ${ }^{\mathrm{TM}}$ method [21]. The obtained pET30a-mCherry and pET30a-psRFP were transformed into E. coli BL21(DE3). The recombinant strains were grown in $\mathrm{LB}$ at $37^{\circ} \mathrm{C}$ with shaking $(210 \mathrm{rpm})$ until the absorbance at $600 \mathrm{~nm}\left(\mathrm{OD}_{600}\right)$ reached about 0.6 , and then $0.4 \mathrm{mM}$ IPTG was added. The cells were further cultured at $25^{\circ} \mathrm{C}$ with shaking (180 rpm) for $20 \mathrm{~h}$. Cells were collected by centrifugation and broken open using a crusher SPCH-18 (Stansted Fluid Power Ltd.,London, UK). Protein purification was carried out with the nickel-nitrilotriacetic acid agarose resin (Invitrogen, New York, USA). SDS-PAGE analysis was performed to analyze the purity of finally obtained proteins. Buffer exchange of the purified proteins was performed with a PD-10 desalting column (GE Healthcare, New York, USA).

\subsection{Characterization of $p s R F P$}

The purified protein $(75 \mu \mathrm{M})$ was mixed with a reactant $\left(200 \mu \mathrm{M} \mathrm{H}_{2} \mathrm{O}_{2}, 200 \mu \mathrm{M} \mathrm{DTT}, 200 \mu \mathrm{M} \mathrm{HS} \mathrm{H}_{\mathrm{H}}\right.$, $200 \mu \mathrm{M}$ GSSH, $1 \mathrm{mM} \mathrm{Na} \mathrm{SO}_{3}$, or $1 \mathrm{mM} \mathrm{Na}_{2} \mathrm{~S}_{2} \mathrm{O}_{3}$ ) in Tris-HCl buffer ( $50 \mathrm{mM}, \mathrm{pH}$ 7.4). The reaction was performed at room temperature for $1 \mathrm{~h}$, and then the unreacted reactants were removed with the PD-10 desalting column. The fluorescence of the reacted protein was analyzed by using a RF-5301 PC spectrofluorophotometer (Shimadzu, Kyoto, Japan). 
The absorbance of purified psRFP and mCherry was analyzed by using a UV-1800 spectrophotometer (Shimadzu, Kyoto, Japan). Equation (1) was used to calculate the quantum yield of psRFP:

$$
\Phi_{x}=\left(A_{s} / A_{x}\right)\left(F_{x} / F_{s}\right)\left(n_{x} / n_{s}\right)^{2} \times \Phi_{s}
$$

In Equation (1), $\Phi$ is the quantum yield, $A$ is the absorbance, $F$ is the total fluorescent emission, $n$ is the refractive index of the solvents used, $x$ is the sample to be detected (psRFP), and $s$ is the standard (mCherry). Equation (2) was used to calculate the extinction coefficient of psRFP:

$$
A=\varepsilon b c
$$

In Equation (2), $A$ is the absorbance, $\varepsilon$ is the extinction coefficient, $b$ is the optical distance, and $c$ is the protein concentration. The brightness of psRFP was calculated by $\Phi \times \varepsilon$.

Redox midpoint potential was detected by using redox-oxidation titrations. Reduced DTT $\left(\mathrm{DTT}_{\text {red }}\right)$ and oxidized DTT $\left(\mathrm{DTT}_{\mathrm{ox}}\right)$ were used to prepare the redox potential buffers, in which the total concentration of DTT $\left(\mathrm{DTT}_{\text {red }}+\mathrm{DTT}_{\mathrm{ox}}\right)$ was $100 \mathrm{mM}$ and the $\mathrm{pH}$ was set to 7.0. By adjusting the $\mathrm{DTT}_{\text {red }}$ to $\mathrm{DTT}_{\mathrm{ox}}$ ratio, we prepared five redox buffers with different redox potentials $(-389,-360$, $-330,-300$, and $-271 \mathrm{mV}$ ). The completely $\mathrm{HS}_{\mathrm{n}} \mathrm{H}$-oxidized psRFP was prepared by reacting $4.4 \mu \mathrm{M}$ purified psRFP with $300 \mu \mathrm{M} \mathrm{HS}_{\mathrm{n}} \mathrm{H}$ at room temperature for $1 \mathrm{~h}$. Unreacted $\mathrm{HS}_{\mathrm{n}} \mathrm{H}$ was removed by a PD-10 desalting column. The completely $\mathrm{HS}_{\mathrm{n}} \mathrm{H}$-oxidized psRFP was added into the redox buffers and incubated at room temperature for $1 \mathrm{~h}$. The $466 / 610 \mathrm{~nm}$ ratios were analyzed by RF-5301 PC and the redox midpoint potential of psRFP, $E_{m(p s R F P)}^{0}$, was calculated using an Equation (3):

$$
E_{D T T}=E_{m(D T T)}^{0}-\frac{R T}{z F} \ln \frac{[D T T]_{r e d}}{[D T T]_{o x}}=E_{m(p s R F P)}^{0}-\frac{R T}{z F} \ln \left(\frac{1-O x D_{p s R F P}}{O x D_{p s R F P}}\right)
$$

In Equation (3), $E_{m(D T T)}^{0}$ is the standard redox midpoint potential of DTT at $\mathrm{pH} 7(-330 \mathrm{mV}), z$ is the number of transferred electrons, $F$ is the Faraday constant $\left(96,485 \mathrm{C} \mathrm{mol}^{-1}\right), R$ is the gas constant $\left(8.315 \mathrm{~J} \mathrm{~K}^{-1} \mathrm{~mol}^{-1}\right)$, and $T$ is the absolute temperature $(298.15 \mathrm{~K}) . O x D_{p s R F P}$ is the percentage of oxidized psRFP (psRFP ${ }_{\text {ox }}$ ) in the system, which was calculated using Equation (4):

$$
O x D_{p s R F P}=\frac{\left[p s R F P_{o x}\right]}{\left[p s R F P_{o x}\right]+\left[p s R F P_{r e d}\right]}=\frac{R-R_{\text {red }}}{R_{o x}-R_{\text {red }}}
$$

In Equation (4), $\mathrm{R}_{\mathrm{ox}}$ and $\mathrm{R}_{\text {red }}$ refer to the $466 / 610 \mathrm{~nm}$ ratios of completely $\mathrm{HS}_{\mathrm{n}} \mathrm{H}$-oxidized psRFP and DTT-reduced psRFP, respectively. $R$ is the $466 / 610 \mathrm{~nm}$ ratio detected by RF-5301 PC. The obtained OxD $D_{\text {pRFF }}$ data were plotted against the redox potential data generated by DTT redox buffers, and the curve was fitted into Equation (3) to calculate the psRFP redox midpoint potential.

\subsection{Liquid Chromatography Tandem Mass Spectrum (LC-MS/MS) Analysis of psRFP}

The purified protein $(75 \mu \mathrm{M})$ was reacted with $300 \mu \mathrm{M} \mathrm{HS}{ }_{n} \mathrm{H}$ or DTT at $25{ }^{\circ} \mathrm{C}$ for $1 \mathrm{~h}$. The reacted mixture was loaded onto a PD-10 desalting column to remove unreacted small molecules. The re-purified proteins $(\leq 100 \mu \mathrm{g})$ were then mixed with $50 \mu \mathrm{L}$ denaturing buffer $(0.5 \mathrm{M}$ Tris- $\mathrm{HCl}$, $2.75 \mathrm{mM}$ Ethylenediaminetetraacetic acid (EDTA), $6 \mathrm{M}$ Guanadine- $\mathrm{HCl}, \mathrm{pH} 8.1$ ) and $50 \mu \mathrm{L} 1 \mathrm{M}$ iodoacetamide (IAM) in a dark place for $1 \mathrm{~h} .360 \mu \mathrm{L}$ of $25 \mathrm{mM} \mathrm{NH}_{4} \mathrm{HCO}_{3}$ was used to wash the mixture four times in a Microcon YM-10 K centrifugal filter unit (Millipore, Billerica, MA, USA). The washed proteins were then digested with trypsin by following a previously reported protocol [22].

The Prominence nano-LC system (Shimadzu, Kyoto, Japan) equipped with a custom-made silica column $(75 \mu \mathrm{m} \times 15 \mathrm{~cm})$ packed with $3 \mu \mathrm{m}$ Reprosil-Pur $120 \mathrm{C} 18$-AQ was used for the analysis. For the elution process, a $100 \mathrm{~min}$ gradient from $0 \%$ to $100 \%$ of solvent $\mathrm{B}(0.1 \%$ formic acid in $98 \%$ acetonitrile) at $300 \mathrm{~nL} / \mathrm{min}$ was used, and solvent $\mathrm{A}$ was $0.1 \%$ formic acid in $2 \%$ acetonitrile. The eluent was ionized 
and electro-sprayed via LTQ-Orbitrap Velos Pro CID mass spectrometer (Thermo Scientific, Waltham, MA, USA), which run in data-dependent acquisition mode with Xcalibur 2.2.0 software (Thermo Scientific, Waltham, MA, USA). The spray voltage was of -3.0 and $3.0 \mathrm{kV}$ in negative and positive modes, respectively. The ion transfer tube temperature was set at $300{ }^{\circ} \mathrm{C}$. Full-scan mass spectra (from 400 to $1800 \mathrm{~m} / \mathrm{z}$ ) were detected in the Orbitrap with a resolution of 60,000 at $400 \mathrm{~m} / \mathrm{z}$.

\subsection{Analysis of Intracellualr Sulfane Sulfur with psRFP}

E. coli BL21(DE3) harboring pET30a-psRFP plasmid (Table 1) was grown in LB medium at $37^{\circ} \mathrm{C}$ with shaking (210 rpm) for 5 h. $10 \mu \mathrm{M}$ IPTG was added at the beginning of the cultivation. After the cultivation, E. coli cells were collected and washed twice with Tris-HCl buffer (50 mM, pH 7.4). E. coli cells were suspended in the Tris buffer at $\mathrm{OD}_{600}$ of 1 and incubated with $2 \mathrm{mM}$ DTT or $200 \mu \mathrm{M}$ sulfur-containing chemicals ( $\mathrm{HS}_{\mathrm{n}} \mathrm{H}, \mathrm{GSSH}$, cystine, or cysteine) at room temperature for $1 \mathrm{~h}$. After the sulfur-containing chemical treatment, cells were washed twice with Tris-HCl buffer and cell concentration was adjusted to $\mathrm{OD}_{600}=1$, and then fluorescence of the cells were analyzed by a Synergy H1 microplate reader.

Table 1. Strains and plasmids used in this study.

\begin{tabular}{|c|c|c|}
\hline Strains and Plasmids & Relevant Characteristics/Purposes & References \\
\hline Strains & & \\
\hline S. cerevisiae BY4742 & $M A T \alpha$ his $3 \Delta 1$ leu $2 \Delta 0$ lys $2 \Delta 0$ ura $3 \Delta 0$ & A gift from Prof. Jin Hou \\
\hline E. coli DH5a & $\begin{array}{l}\text { supE44, AlacU169 (q80lacZAM15), hsdR17, recA1, endA1, } \\
\text { gyrA96,thi-1, relA1. For cloning and plasmid construction }\end{array}$ & Lab stock \\
\hline E. coli BL21(DE3) & $\begin{array}{l}\text { F-ompT hsdSB (rB-mB-) gal ( } \lambda 1857 \text { ind } 1 \text { Sam } 7 \text { nin } 5 \text { lacUV } 5 \\
\text { T7gene1) dcm. For expression and protein purification }\end{array}$ & Lab stock \\
\hline \multicolumn{3}{|c|}{ 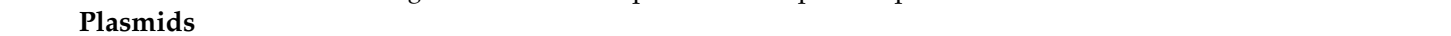 } \\
\hline YEplac195-psGFPcyt & YEplac195 containing psRFP. Under control of TEF1 promoter & This study \\
\hline YEplac195-psGFPmit & $\begin{array}{l}\text { YEplac195 containing an N-ternimus sigal peptide }{ }^{\mathrm{a}} \text {-psRFP. } \\
\text { Under control of TEF1 promoter }\end{array}$ & This study \\
\hline pET30a-psRFP & $\begin{array}{l}\text { pET30a containing psRFP. Under control of T7 promoter for } \\
\text { expression and protein purification }\end{array}$ & This study \\
\hline pET30a-mCherry & $\begin{array}{c}\text { pET30a containing mCherry. Under control of T7 promoter for } \\
\text { expression and protein purification }\end{array}$ & This study \\
\hline
\end{tabular}

a The peptide sequence is MLSARSAIKRPIVRGLATV.

For S. cerevisiae in vivo experiments, YEPlac195 plasmid containing TEF1 promoter was used for

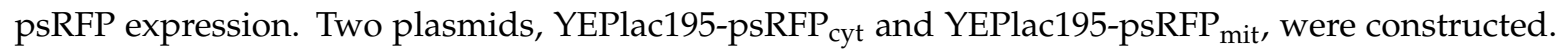
YEPlac195-psRFP cyt $_{\text {was }}$ used to express psRFP in cytoplasm, in which the psRFP encoding gene was directly incorporated into YEPlac195, after the TEF1 promoter. YEPlac195-psRFP ${ }_{\text {mit }}$ was used to express psRFP in mitochondria, in which, the MLSARSAIKRPIVRGLATV leading peptide was fused to the $N$-terminus of psRFP. The two plasmids were transformed into S. cerevisiae BY4742. Transformants were selected from SD-ura medium. The localization of psRFP in mitochondria was tested with Mito Tracker ${ }^{\mathrm{TM}}$ Green (Thermo Scientific) following the manufacturer's introduction. Recombinant S. cerevisiae strains were cultured in SD-ura ${ }^{-}$medium at $30^{\circ} \mathrm{C}$ with shaking (210 rpm). The middle-log phased cells $\left(\mathrm{OD}_{600}=1\right)$ were collected and washed twice with Tris- $\mathrm{HCl}$ buffer $(50 \mathrm{mM}$, $\mathrm{pH} 7.4$ ), and incubated with $2 \mathrm{mM}$ DTT or sulfur-containing chemicals ( $200 \mu \mathrm{M} \mathrm{HS} \mathrm{n}_{\mathrm{H}}$, cystine, cysteine, $\mathrm{Na}_{2} \mathrm{~S}_{2} \mathrm{O}_{3}$ ) at room temperature for $1 \mathrm{~h}$. After the sulfur-containing chemical treatment, cells were washed twice with Tris- $\mathrm{HCl}$ buffer and cell concentration was adjusted to $\mathrm{OD}_{600}=1$. The fluorescence of cell suspensions was analyzed by using a Synergy H1 microplate reader. 


\section{Results}

\subsection{Design of the Reactive Sulfane Sulfur-Sensitive mCherry}

To avoid the disturbance caused by extracellular and intracellular compounds, we chose mCherry as the starting probe because its emission wavelength $\left(\lambda_{\mathrm{em}, \max }=610 \mathrm{~nm}\right)$ is out of the green range. The designing principle is to mutate two amino acid residues, whose locations are near the chromophore, to cysteine residues. Through controlling the distance of thiol groups of the two cysteine residues, a bridge with a $-S_{n}-(n \geq 3)$ bond can be formed when the probe reacts with reactive sulfane sulfur (Figure 1a). The $-S_{n}$ - bond has $\pi$ electrons, hence, it may affect the electron distribution of mCherry chromophore, thereby altering the excitation and/or emission wavelength of mCherry chromophore. Out of the consideration that $-S_{n}$ - (disulfide) bond may have the same effect, which is easily formed when the mutant probe encounters ROS, the distance between the two thiol groups should be longer than $2.05 \AA$, the length of a disulfide bond [23].

a
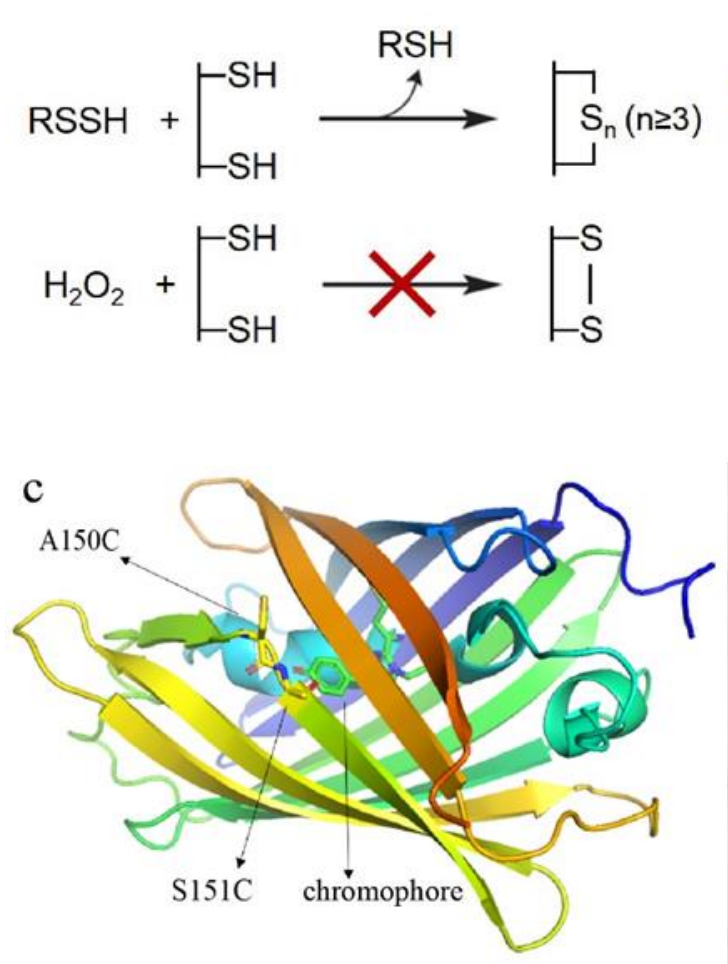

b
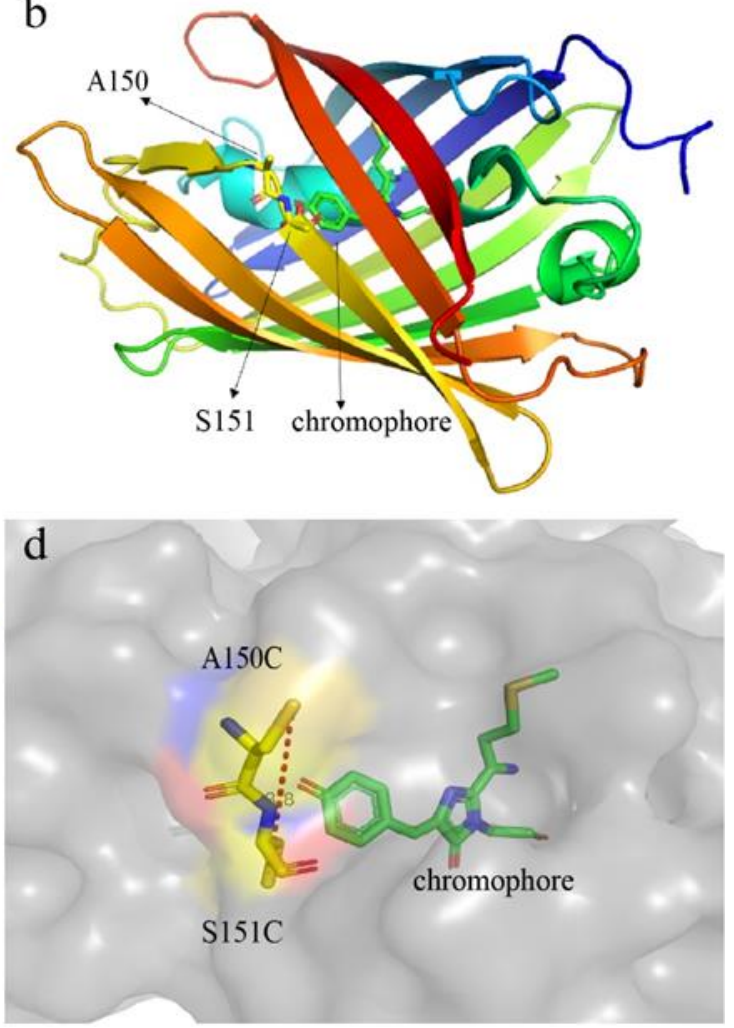

Figure 1. Designing principle and structure analysis of the reactive sulfane sulfur-sensitive mCherry. (a) Schematic representation of the reaction mechanisms. Reactive sulfane sulfur can transfer sulfane sulfur atom(s) to cysteine residues of the mCherry mutant to form an intramolecular $-S_{n}-(n \geq 3)$ bond; however, the $-\mathrm{S}_{2}$ - bond cannot be formed via $\mathrm{H}_{2} \mathrm{O}_{2}$ oxidation due to the long distance $(>2.05 \AA)$ between two thiol groups. (b) The locations of A150 and S151 in mCherry. The three-dimensional (3D) structure of mCherry was downloaded from the PDB website (PDB ID: 2H5Q). (c,d) The locations of C150 and $\mathrm{C} 151$, and the distance between their thiol groups in the mCherry mutant. The 3D structure of mCherry mutant was generated using SWISS-MODEL (http://swissmodel.expasy.org/) with mCherry as the template. The distance was analyzed with PyMol 1.5.0.3.

We used the three-dimensional (3D) structure of mCherry (PDB ID: 2H5Q) as a template and a homology modeling method to analyze the structure of mCherry mutant and found that converting A150 and S151 (Figure 1b) to cysteines might result in the potential probe. The thiol groups of this 
mutant were near to the chromophore (Figure 1c), and the calculated distance between them was $8.8 \AA$ (Figure 1d).

\subsection{Construction of the Hydrogen Polysulfide-Sensitive mCherry}

We constructed the A150C-S151C double mutant and expressed it in E. coli. The mutant was fused with a C-terminus His-tag and was purified using the nickel column. SDS-PAGE analysis showed that the purity of the finally obtained protein was $74 \%$. Fluorescence analysis indicated that the mutant had two obvious differences from the wild-type mCherry (wt): its $610 \mathrm{~nm}$ emission fluorescence (excitation at $\lambda=587 \mathrm{~nm}$ ) dramatically decreased after it reacted with $\mathrm{HS}_{\mathrm{n}} \mathrm{H}$, while the fluorescence had no change after it reacted with $\mathrm{H}_{2} \mathrm{O}_{2}$ (Figure 2a). In comparison, the $610 \mathrm{~nm}$ emission fluorescence of wt was not affected by either $\mathrm{HS}_{\mathrm{n}} \mathrm{H}$ or $\mathrm{H}_{2} \mathrm{O}_{2}$. It showed a new fluorescence spectra with $\lambda_{\text {ex, } \max }=406 \mathrm{~nm}$ and $\lambda_{\mathrm{em}, \max }=466 \mathrm{~nm}$. This fluorescence slightly increased when it reacted with $\mathrm{HS}_{\mathrm{n}} \mathrm{H}$ but slightly decreased when it reacted with $\mathrm{H}_{2} \mathrm{O}_{2}$ (Figure $2 \mathrm{~b}$ ). This new fluorescence spectra was not observed from the wt. These results indicated that the A150C-S151C mutant has potentials to be used as a reactive sulfane sulfur detection probe. Hereafter, in this paper, we designate it as psRFP.

a

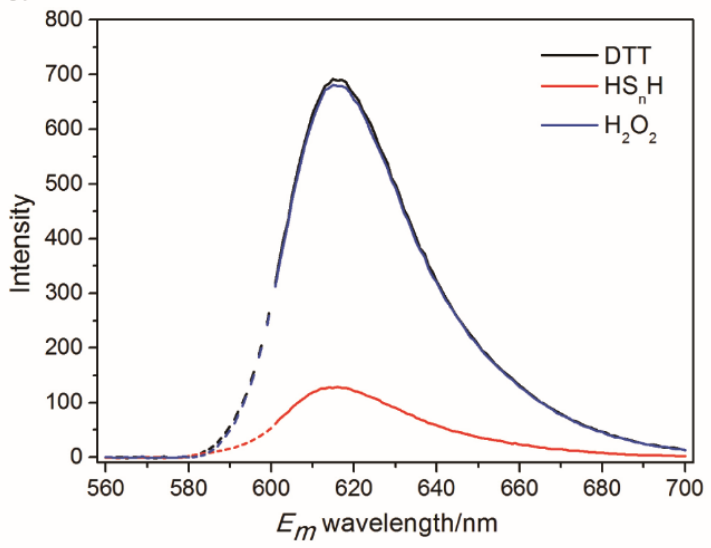

b

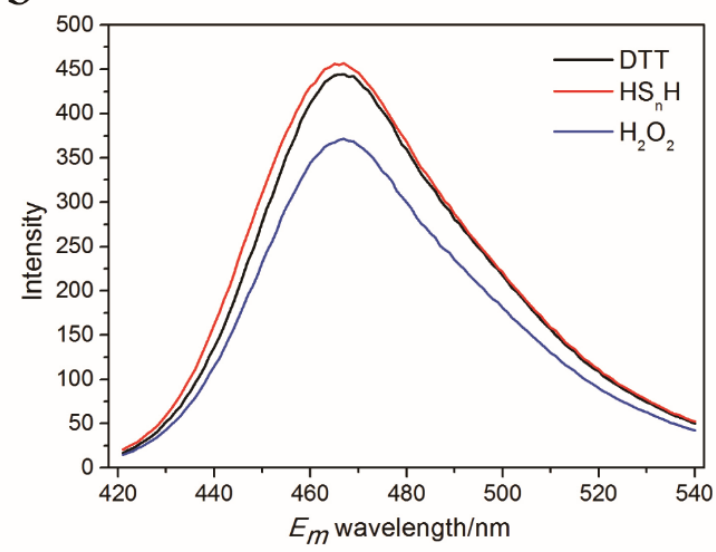

Figure 2. Emission spectra of Dithiothreitol (DTT), hydrogen polysulfide $\left(\mathrm{HS}_{n} \mathrm{H}\right)$, and $\mathrm{H}_{2} \mathrm{O}_{2}$-reacted psRFP at $587 \mathrm{~nm}$ excitation (a) and $406 \mathrm{~nm}$ excitation (b). $75 \mu \mathrm{M}$ purified psRFP was mixed with a reactant $\left(200 \mu \mathrm{M} \mathrm{H}_{2} \mathrm{O}_{2}, 200 \mu \mathrm{M}\right.$ DTT, $\left.200 \mu \mathrm{M} \mathrm{HS}_{\mathrm{n}} \mathrm{H}\right)$ in Tris- $\mathrm{HCl}$ buffer ( $50 \mathrm{mM}, \mathrm{pH}$ 7.4). The reaction was performed at room temperature for $1 \mathrm{~h}$, and then the unreacted reactants were removed with a PD-10 desalting column. The fluorescence of the reacted protein was analyzed by a RF-5301 PC spectrofluorophotometer.

\subsection{In Vitro Test of psRFP}

We analyzed both $\mathrm{HS}_{\mathrm{n}} \mathrm{H}$-reacted psRFP and DTT-reacted psRFP with LTQ-Orbitrap Tandem MS. Two peptides containing $150 \mathrm{C}$ and $151 \mathrm{C}$ were detected in the $\mathrm{HS}_{\mathrm{n}} \mathrm{H}$-reacted psRFP, the first one had a $30.07 \mathrm{Da}(+\mathrm{S},-2 \mathrm{H})$ addition between the two cysteine residues, suggesting that a $-\mathrm{S}_{3}-$ bond was formed (Figure 3a). Its counterpart was also found in the DTT-reacted psRFP, which has no sulfur addition between 150C and 151C (Figure 3b). The second peptide had a $94.2(+3 S,-4 \mathrm{H})$ addition between $150 \mathrm{C}$ and $151 \mathrm{C}$, suggesting that a $-\mathrm{S}_{5}-$ bond was formed (Figure $3 \mathrm{c}$ ). Its counterpart was also found in the DTT-reacted psRFP, which has no sulfur addition (Figure 3d). 
a S

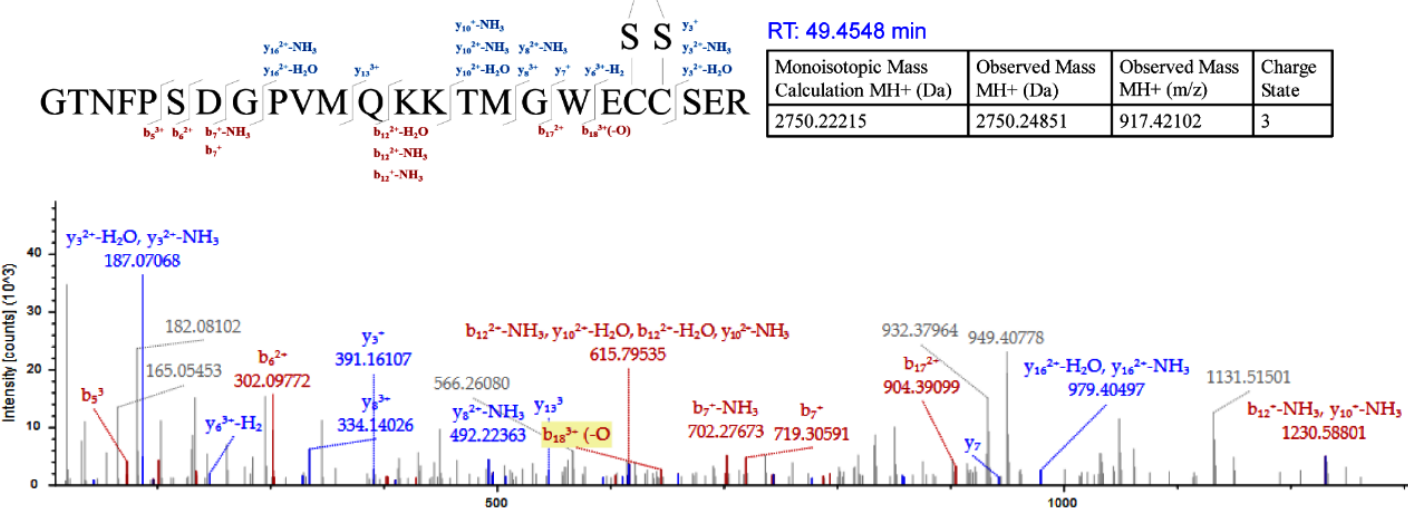

b
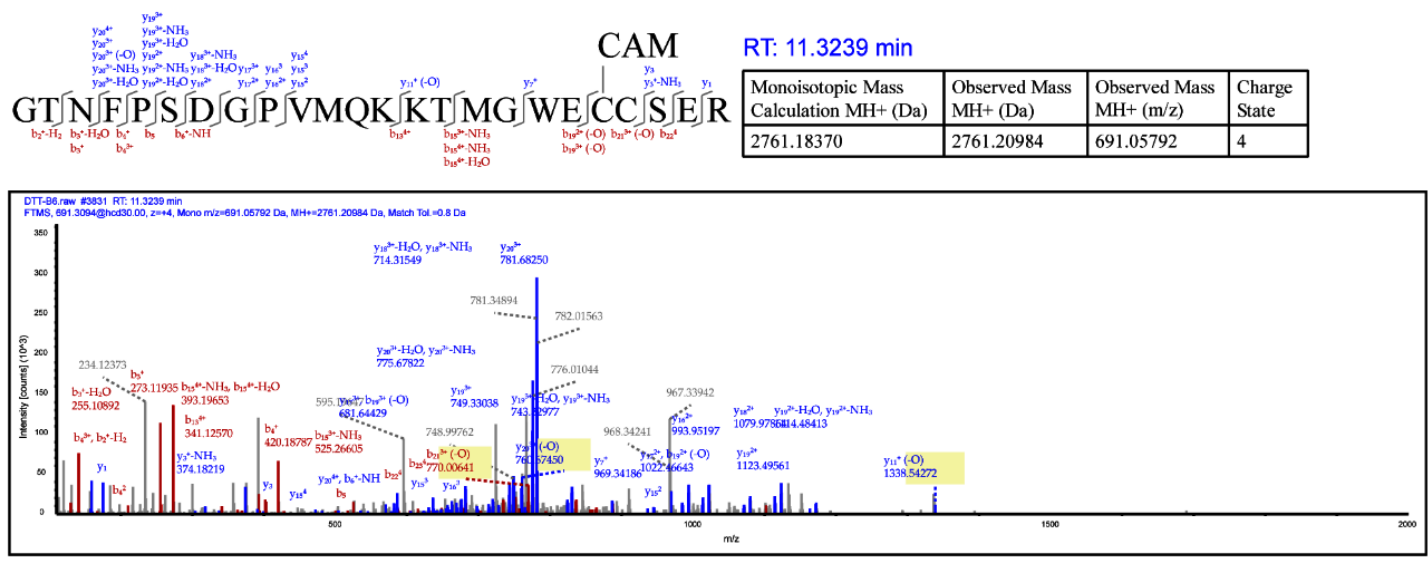

c
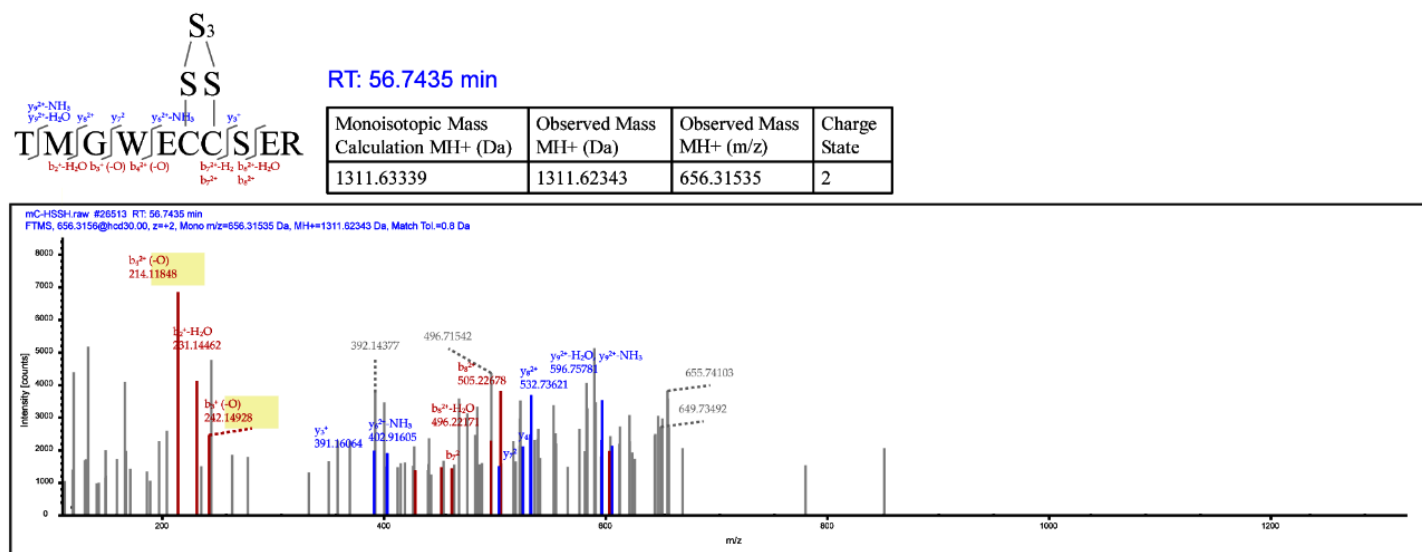

d
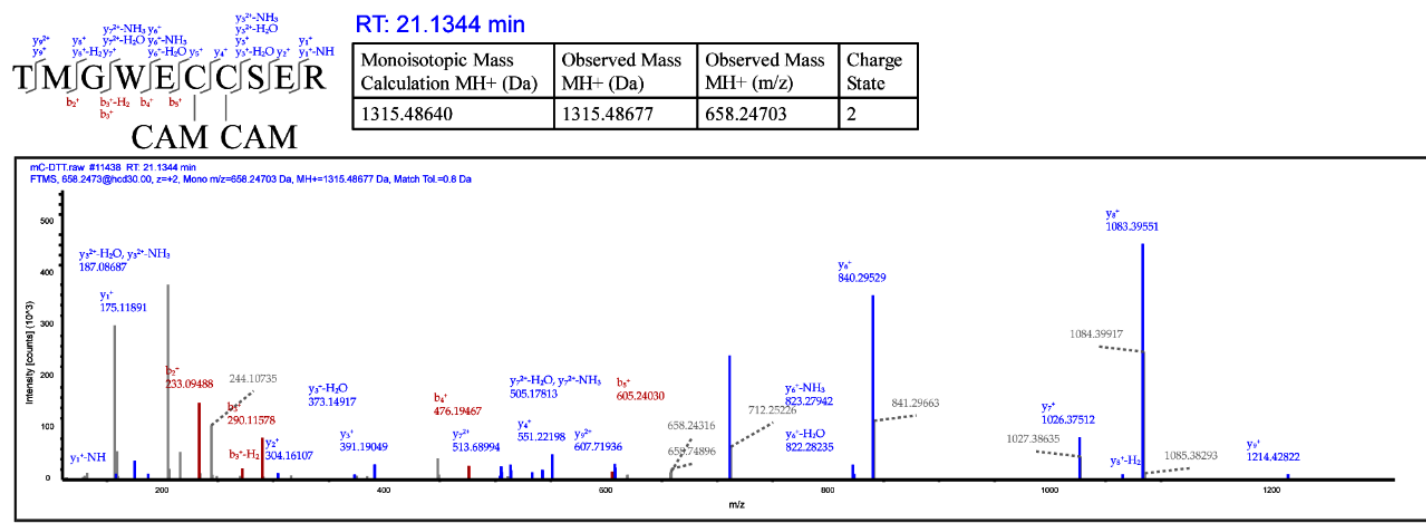

Figure 3. Liquid Chromatography tandem Mass Spectrum (LC-MS/MS) analysis of $\mathrm{HS}_{\mathrm{n}} \mathrm{H}$-reacted psRFP. (a) and (c) are from $\mathrm{HS}_{\mathrm{n}} \mathrm{H}$-reacted psRFP. (b) and (d) are from DTT-reacted psRFP. 
Since the $\mathrm{HS}_{\mathrm{n}} \mathrm{H}$ reaction resulted in both the increase of $466 \mathrm{~nm}$ emission and the decrease of $610 \mathrm{~nm}$ emission, we used the $466 / 610 \mathrm{~nm}$ emission ratio to indicate the proportion of $\mathrm{HS}_{\mathrm{n}} \mathrm{H}$-oxidized psRFP (containing a $-S_{n}-$ bond) to reduced psRFP (containing -SH groups) in the reacted psRFP samples. For the DTT-reacted psRFP sample, the ratio was 0.51 . For the $\mathrm{H}_{2} \mathrm{O}_{2}$-reacted sample, the ratio was 0.44 (Figure 4a), indicating that ROS-related reactions had minimal disturbance to the $466 / 610 \mathrm{~nm}$ emission ratio of psRFP. For the $\mathrm{HS}_{\mathrm{n}} \mathrm{H}$-reacted psRFP sample, the ratio was 2.39. We also used other sulfur-containing chemicals that commonly exist in cells to react with psRFP. Glutathione persulfide (GSSH) caused a mild change to the $466 / 610 \mathrm{~nm}$ emission ratio, while sulfite $\left(\mathrm{Na}_{2} \mathrm{SO}_{3}\right)$ and thiosulfate $\left(\mathrm{Na}_{2} \mathrm{~S}_{2} \mathrm{O}_{3}\right)$ showed no effect. These results indicated that psRFP preferred to react with reactive sulfane sulfur.
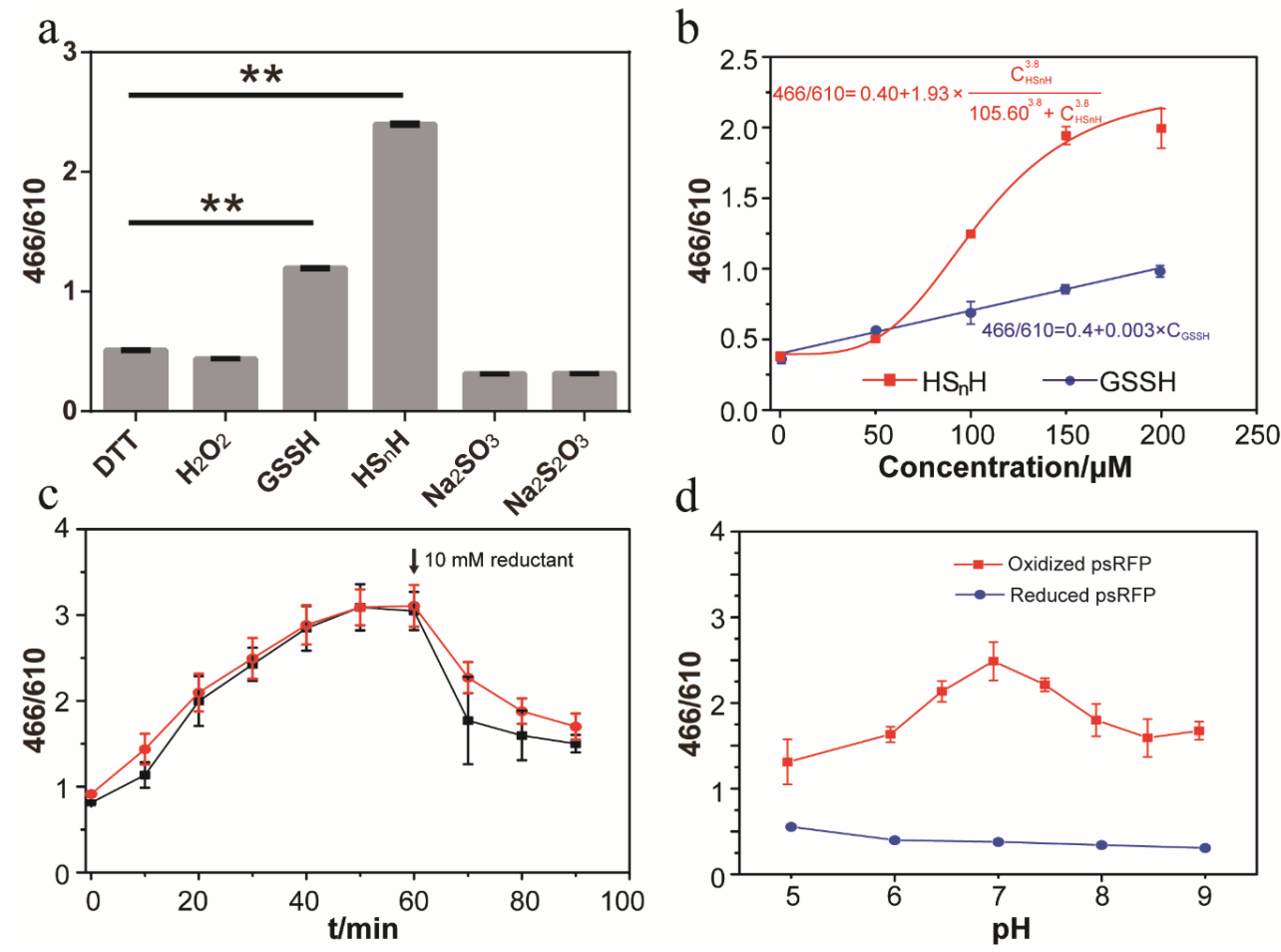

Figure 4. In vitro characterization of psRFP. (a) 466/610 nm emission ratios of reacted psRFP. Symbol ** indicates that the sample is significantly different $(p<0.01)$ from that of DTT-reacted psRFP. (b) Dose-dependent response of psRFP to glutathione persulfide (GSSH) and hydrogen polysulfide $\left(\mathrm{HS}_{\mathrm{n}} \mathrm{H}\right)$. Hill equation was used to fit the data obtained from the psRFP-HS $\mathrm{H}$ reaction and linear equation was used to fit the data obtained from the psRFP-GSSH reaction. (c) DTT (black line) and reduced glutathione (GSH) (red line) reduced the $\mathrm{HS}_{\mathrm{n}} \mathrm{H}$-reacted psRFP. (d) $\mathrm{pH}$ effects to the $466 / 610 \mathrm{~nm}$ emission ratios of reduced psRFP (reacted with DTT) and $\mathrm{HS}_{\mathrm{n}} \mathrm{H}$-oxidized psRFP (reacted with $\mathrm{HS}_{\mathrm{n}} \mathrm{H}$ ). For (a), $75 \mu \mathrm{M}$ purified psRFP was mixed with a reactant $\left(200 \mu \mathrm{M} \mathrm{H}_{2} \mathrm{O}_{2}, 200 \mu \mathrm{M}\right.$ DTT, $200 \mu \mathrm{M} \mathrm{HS} \mathrm{n}_{\mathrm{H}}$, $200 \mu \mathrm{M} \mathrm{GSSH}, 1 \mathrm{mM} \mathrm{Na}_{2} \mathrm{SO}_{3}$, or $1 \mathrm{mM} \mathrm{Na}_{2} \mathrm{~S}_{2} \mathrm{O}_{3}$ ) in Tris- $\mathrm{HCl}$ buffer $(50 \mathrm{mM}, \mathrm{pH}$ 7.4). The reaction was performed at room temperature for $1 \mathrm{~h}$, and then the unreacted reactants were removed with a PD-10 desalting column. For (b), the reaction conditions were the same, except for that the concentrations of GSSH and $\mathrm{HS}_{n} \mathrm{H}$ were different. For (c), $75 \mu \mathrm{M}$ purified psRFP was mixed with $200 \mu \mathrm{M} \mathrm{HS} \mathrm{S}_{n} \mathrm{H}$ in Tris- $\mathrm{HCl}$ buffer $(50 \mathrm{mM}, \mathrm{pH}$ 7.4). The reaction was performed at room temperature. An increase of the $466 / 610 \mathrm{~nm}$ emission ratio was observed. When $10 \mathrm{mM}$ DTT (red line) or GSH (black line) was added at $60 \mathrm{~min}$, the ratio quickly decreased in $10 \mathrm{~min}$. For (d), the reaction conditions were the same as in (a), except for that the reaction buffer was changed to phosphate buffer $(67 \mathrm{mM}, \mathrm{pH} 5.0,6.0$, or 6.5) or Tris-HCl buffer (50 mM, pH 7.0, 7.5, 8.0, 8.5, or 9.0). The fluorescence of the reacted proteins were all analyzed by a RF-5301 PC spectrofluorophotometer. The data of (a-d) were from three independent repeats and shown as mean value \pm standard deviation (SD). 
The above reactions were conducted in a condition that the concentrations of reactants were much higher than that of psRFP. Next, we used gradient concentrations of $\mathrm{HS}_{\mathrm{n}} \mathrm{H}$ and GSSH to react the psRFP. The values of the $466 / 610 \mathrm{~nm}$ emission ratio were linearly dependent on the concentrations of the reactants (Figure $4 b$ ). We used the Hill equation to fit the data obtained from the psRFP-HS $\mathrm{H}$ reaction. Parameters showed that the $\mathrm{K}_{\mathrm{m}}$ is 105.6 and the Hill coefficient is 3.8. Under the applied condition, the detection range for $\mathrm{HS}_{\mathrm{n}} \mathrm{H}$ is $50 \sim 200 \mu \mathrm{M}$. We used the linear equation to fit the data obtained from the psRFP-GSSH reaction. Parameters showed that the slope is 0.003 and the intercept is 0.4. psRFP showed higher sensitivity toward $\mathrm{HS}_{\mathrm{n}} \mathrm{H}$ than $\mathrm{GSSH}$, probably because $\mathrm{HS}_{\mathrm{n}} \mathrm{H}$ is more active than GSSH [7].

When psRFP was mixed with $\mathrm{HS}_{\mathrm{n}} \mathrm{H}$, the 466/610 $\mathrm{nm}$ emission ratio gradually increased and reached the maximum at $50 \mathrm{~min}$, and when $10 \mathrm{mM}$ DTT was added at $60 \mathrm{~min}$, the ratio quickly decreased in $10 \mathrm{~min}$ (Figure 4c). This observation indicated that the $\mathrm{HS}_{\mathrm{n}} \mathrm{H}$-oxidized psRFP was reducible by DTT. Since GSH is an important antioxidant in many cells, we checked whether it can reduce the $\mathrm{HS}_{\mathrm{n}} \mathrm{H}$-oxidized psRFP or not. Results showed that when $10 \mathrm{mM}$ GSH was mixed with the $\mathrm{HS}_{\mathrm{n}} \mathrm{H}$-oxidized psRFP, the 466/610 nm emission ratio was also decreased, although with less degree compared to that caused by $10 \mathrm{mM}$ DTT (Figure $4 \mathrm{c}$ ).

We tested the $\mathrm{pH}$ effect to the 466/610 ratio of reduced and $\mathrm{HS}_{\mathrm{n}} \mathrm{H}$-oxidized psRFP. The 466/610 ratio of reduced psRFP (DTT-treated) was a little higher at $\mathrm{pH} 5.0$ than that at $\mathrm{pH} 9.0$, but in the range of $\mathrm{pH} 6 \sim 8$, the ratio change was negligible (Figure 4d). For the HS $\mathrm{H}$-oxidized psRFP, the 466/610 ratio was significantly higher at neutral $\mathrm{pH}(7.0)$ than at acidic or alkaline $\mathrm{pH}$. In the tested $\mathrm{pH}$ range, the $466 / 610$ ratios of $\mathrm{HS}_{\mathrm{n}} \mathrm{H}$-oxidized psRFP were always higher than those of reduced psRFP, indicating that psRFP can be used to detect sulfane sulfur in different $\mathrm{pH}$ conditions.

Using the redox-oxidation titration method and DTT (whose redox midpoint potential is $-330 \mathrm{mV}$ ) solutions as the calibrating redox buffer, we measured the redox midpoint potential of psRFP to be $-363 \mathrm{mV}$ at $\mathrm{pH} 7.0$ and $25^{\circ} \mathrm{C}$. We also measured the quantum yield $(\Phi)$, extinction coefficient $(\varepsilon)$, and brightness of psRFP $\left(\lambda_{\mathrm{em}}=610 \mathrm{~nm}\right.$, in reduced form, Table 2$)$. These photophysical parameters were all lower than those of mCherry (Table 2).

Table 2. Photophysical parameters of mCherry and psRFP.

\begin{tabular}{ccccc}
\hline & $\boldsymbol{\Phi}$ & $\mathbf{( M}^{\left.\mathbf{- 1} \cdot \mathbf{c m}^{-\mathbf{1}} \times \mathbf{1 0}^{-\mathbf{3}}\right)}$ & Brightness & $\boldsymbol{E}_{\boldsymbol{m}}^{0}(\mathbf{m v})$ \\
\hline MCherry $^{1}$ & 0.22 & 72 & 15.84 & n.d. $^{2}$ \\
psRFP $^{2}$ & 0.0076 & 5.4 & 0.04 & -363 \\
\hline
\end{tabular}

1 The parameters were referred to in References [24,25]. ${ }^{2}$ mCherry has no cysteine residues; hence, its redox potential was not analyzed.

\subsection{In Vivo Test of psRFP}

To evaluate the cellular interference to the blue fluorescence at $466 \mathrm{~nm}$, we analyzed the flavin mononucleotide (FMN), the common intracellular chromophore that has strong $528 \mathrm{~nm}$ emission fluorescence (excited at $485 \mathrm{~nm}$ ). Its $466 \mathrm{~nm}$ emission fluorescence (excited at $406 \mathrm{~nm}$ ) was about 60-fold lower that of $528 \mathrm{~nm}$ and was only slightly higher than the Tris-HCl buffer (Figure 5). These results indicated that FMN cannot interfere with the mCherry-based probe. We also analyzed the fluorescence of E. coli and S. cerevisiae cells and observed that again, the $466 \mathrm{~nm}$ fluorescence is relatively weak; hence, the cellular interference to the psRFP probe is limited.

Next, we used psRFP to detect the intracellular sulfane sulfur of E. coli BL21 (DE3). E. coli cells expressing psRFP were incubated with different sulfur-containing chemicals, and the 466/610 ratios were measured. Both $\mathrm{HS}_{\mathrm{n}} \mathrm{H}$ - and GSSH-treated cells had obviously higher 466/610 ratios than DTT-treated (Figure 6a), demonstrating that sulfane sulfur-treated cells had more intracellular reactive sulfane sulfur, as expected. In comparison, cystine or cysteine treatment did not lead to obvious 
increases of the $466 / 610$ ratio, indicating that they had no or minimum effect to the level of intracellular reactive sulfane sulfur.

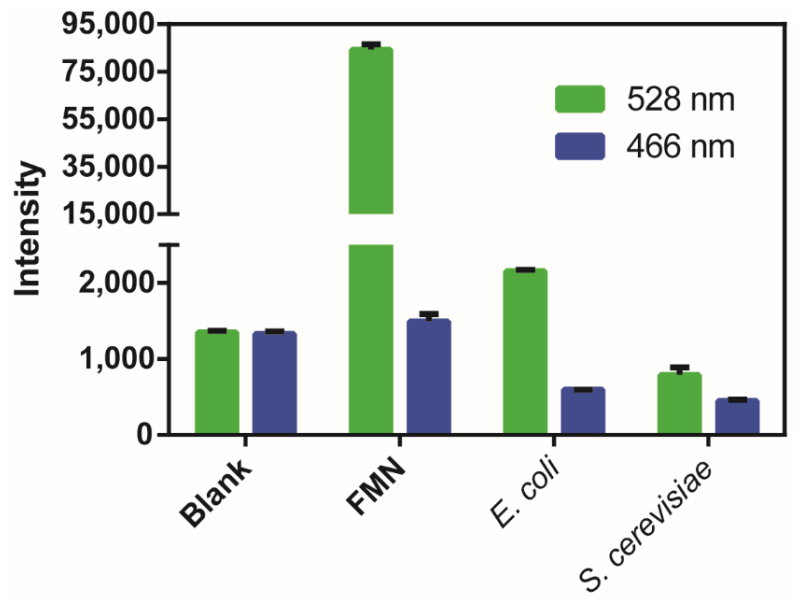

Figure 5. Fluorescence analysis of flavin mononucleotide (FMN), E. coli, and S. cerevisiae cells. A Synergy H1 microplate reader was used and the $528 \mathrm{~nm}$ emission fluorescence was excited at $485 \mathrm{~nm}$, and the $466 \mathrm{~nm}$ emission fluorescence was excited at $406 \mathrm{~nm}$. Blank is the Tris- $\mathrm{HCl}$ buffer $(50 \mathrm{mM}, \mathrm{pH} 7.4)$. FMN $(50 \mu \mathrm{M})$, E. coli, and S. cerevisiae cells $\left(\mathrm{OD}_{600}=1\right)$ were suspended in the Tris-HCl buffer $(50 \mathrm{mM}$, $\mathrm{pH}$ 7.4). The data were from three independent repeats and shown as mean value \pm SD.
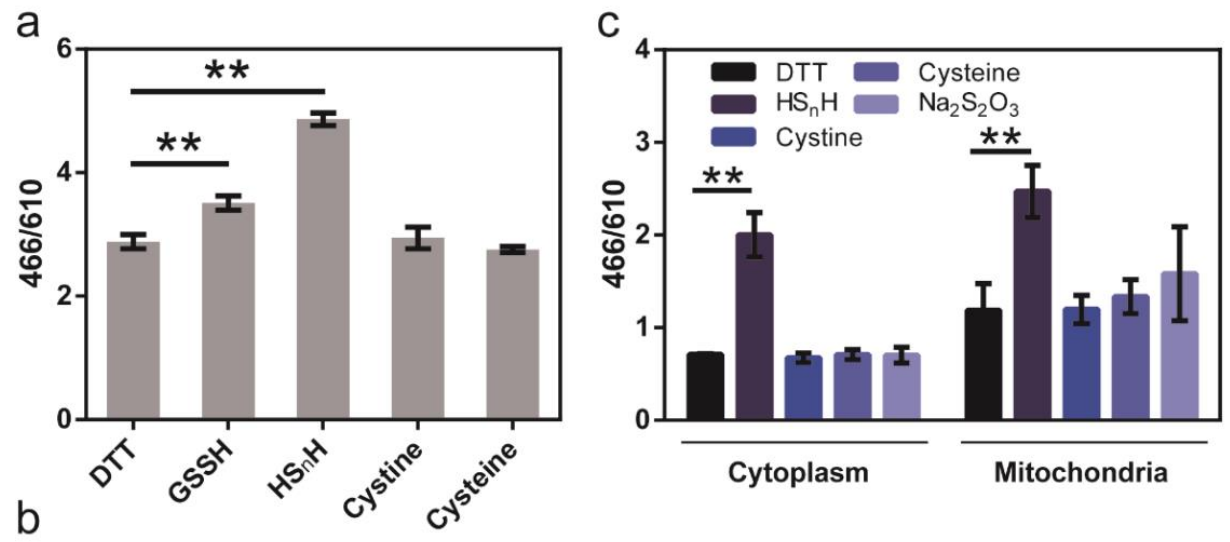

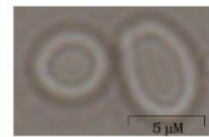

BF

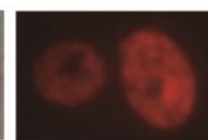

psRFP

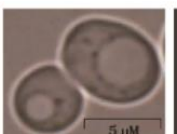

BF

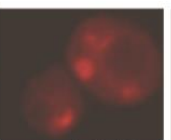

psRFP

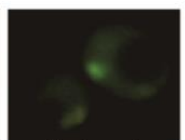

mitotracker

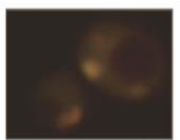

merged

Cytoplasm

Mitochondria

Figure 6. Using the psRFP to analyze intracellular reactive sulfane sulfur. (a) psRFP was expressed in cytoplasm of E. coli BL21(DE3). E. coli cells $\left(\mathrm{OD}_{600}=1\right)$ were collected and washed twice with Tris- $\mathrm{HCl}$ (50 mM, pH 7.4), and then incubated with $2 \mathrm{mM}$ DTT or $200 \mu \mathrm{M}$ sulfur-containing chemicals $\left(\mathrm{HS}_{\mathrm{n}} \mathrm{H}\right.$, GSSH, cystine, or cysteine) at room temperature for $1 \mathrm{~h}$. The data were from three independent repeats and shown as mean value \pm SD. Symbol ${ }^{* *}$ indicates that the sample is significantly different $(p<0.01)$ from DTT-treated cells. (b) psRFP was expressed in S. cerevisiae BY4742 cytoplasm or mitochondria. Photos were captured with an Olympus fluorescence microscope (IX83, 63×). (c) S. cerevisiae cells $\left(\mathrm{OD}_{600}=1\right)$ were collected and washed twice with Tris- $\mathrm{HCl}(50 \mathrm{mM}, \mathrm{pH} 7.4)$, and then incubated with $2 \mathrm{mM}$ DTT or sulfur-containing chemcials $\left(200 \mu \mathrm{M} \mathrm{HS}{ }_{n} \mathrm{H}\right.$, cystine, cysteine, $\left.\mathrm{Na}_{2} \mathrm{~S}_{2} \mathrm{O}_{3}\right)$ at room temperature for $1 \mathrm{~h}$. The fluorescence of both E. coli and S. cerevisiae cells was analyzed with a Synergy H1 microplate reader. The data were from three independent repeats and shown as mean value \pm SD. Symbol ** indicates the sample is significantly different $(p<0.01)$ from the DTT-treated sample. 
We then used psRFP to analyze the intracellular reactive sulfane sulfur of S. cerevisiae BY4742. It was expressed in BY4742 cytoplasm and mitochondria. For expression in cytoplasm, psRFP contained no signal peptide. For expression in mitochondria, psRFP was fused with an N-terminal signal peptide MLSARSAIKRPIVRGLATV. The recombinant yeast cells were treated with different sulfur-containing chemicals, and the 466/610 ratios were measured (Figure 6b). $\mathrm{HS}_{\mathrm{n}} \mathrm{H}$ treatment led to an obvious increase of 466/610 ratios in both cytoplasm and mitochondria. Cysteine and thiosulfate caused slight increases of 466/610 ratios in mitochondria, but not in cytoplasm. In addition, the 466/610 ratios in mitochondria were generally higher than those in cytoplasm, suggesting that mitochondria should be the major production organelle in S. cerevisiae.

\section{Discussion}

Although some chemically synthesized probes have been developed for detection of reactive sulfane sulfur in vivo, only several of them are commercially available, making their application limited [26-31]. In this study, we developed an easily available, mCherry-based, and reaction-reversible probe that enables real-time analysis of intracellular reactive sulfane sulfur. The working mechanism of psRFP is when, reacting with reactive sulfane sulfur, an intramolecular $-S_{n}-$ bond can be formed between its two cysteine residues. The $610 \mathrm{~nm}$ emission fluorescence intensity decreased from 690 to 110 after it reacted with $\mathrm{HS}_{\mathrm{n}} \mathrm{H}$ (detected by the RF-5301 PC spectrofluorophotometer), the amplitude of the change was 580. This amplitude is large enough to be detected in a common fluorophotometer. Therefore, it is suitable for reactive sulfane sulfur detection, as confirmed by in vivo experiments. We also observed that psRFP had a new fluorescence peak $\left(\lambda_{\mathrm{ex}, \max }=406 \mathrm{~nm}\right.$ and $\left.\lambda_{\mathrm{em}, \max }=466 \mathrm{~nm}\right)$, which is slightly affected by the $-S_{n}$ - bond. The $466 / 610 \mathrm{~nm}$ emission ratio can directly indicate the proportion of $\mathrm{HS}_{\mathrm{n}} \mathrm{H}$-oxidized psRFP to reduced psRFP; therefore, this probe can be used in both in vitro and in vivo detection of cellular reactive sulfane sulfur. It is noteworthy that the oxidized psRFP can be reduced by GSH; therefore, the reactive sulfane sulfur level detected by psRFP may to some extent reflect the GSH level in the cell. Actually, GSH can directly react with reactive sulfane sulfur and their complex reactions have been intensely studied [1,2,8-10]. The level of reactive sulfane sulfur itself is a compromised consequence of the complex reactions among sulfane sulfur, GSH, and hydrogen sulfide.

Compared with the GFP-based probe psGFP1.1, psRFP has similar detection range and sensitivity. The reaction time of psRFP with $\mathrm{HS}_{\mathrm{n}} \mathrm{H}$ is longer ( $\left.\sim 50 \mathrm{~min}\right)$ than that of psGFP1.1 with $\mathrm{HS}_{\mathrm{n}} \mathrm{H}(\sim 15 \mathrm{~min})$. The most important difference between them is that psRFP has no emission fluorescence at the $\sim 500 \mathrm{~nm}$ range; hence, it can be used simultaneously with other cell dyes or probes having green fluorescence. In addition, its fluorescence signal is less disturbed by cell components. A disadvantage of psRFP is that its brightness $\left(\lambda_{\mathrm{em}}=610 \mathrm{~nm}\right)$ is much lower than that of mCherry (Table 2). In contrast, psGFP1.1 shows no significant brightness decrease compared to its parental GFP [9]. The low brightness is not a severe drawback when psRFP is applied in analysis of E. coli or S. cerevisiae, because high concentrations of psRFP can be achieved via using plasmids for its expression. However, when we tried to use it for analysis of the human colorectal carcinoma cell HCT116, we observed that the fluorescence signals were too low to give a meaningful indication (data not shown). The reason why 150C-S151C double mutations cause this brightness decrease is still unknown. To develop a mammalian cell-friendly probe, the same mutation strategy might be applied to other red fluorescence proteins, and the mutant whose brightness is less changed should be preferred.

\section{Conclusions}

A mCherry mutant was constructed by mutating two amino acid residues (A150 and S151) to cysteine residues. Thiol groups of these two cysteine residues can react with reactive sulfane sulfur to form an intramolecular $-S_{n}$ - bond $(n \geq 3)$. The bond largely decreases the intensity of $610 \mathrm{~nm}$ emission (excitation at $587 \mathrm{~nm}$ ) and slightly increases the intensity of $466 \mathrm{~nm}$ emission (excitation at $406 \mathrm{~nm}$ ). Therefore, the $466 / 610 \mathrm{~nm}$ emission ratio can be used to indicate the relative abundance of reactive 
sulfane sulfur. By expressing the mCherry mutant in the cell, in vivo reactive sulfane sulfur can be dynamically detected.

Author Contributions: Conceptualization, writing-original draft preparation, project administration, and supervision, H.L.; Investigation, methodology, data curation, and software, Z.L. and Q.W.; writing-review and editing, Y.X. and L.X. All authors have read and agreed to the published version of the manuscript.

Funding: This research was funded by the National Key Research and Development Program of China (2018YFA0901200, 2016YFA0601103, 91951202).

Conflicts of Interest: The authors declare no conflict of interest.

\section{References}

1. Giles, G.I.; Nasim, M.J.; Ali, W.; Jacob, C. The reactive sulfur species concept: 15 years on. Antioxidants 2017, 6, 38. [CrossRef] [PubMed]

2. Fukuto, J.M.; Ignarro, L.J.; Nagy, P.; Wink, D.A.; Kevil, C.G.; Feelisch, M.; Cortese-Krott, M.M.; Bianco, C.L.; Kumagai, Y.; Hobbs, A.J.; et al. Biological hydropersulfides and related polysulfides-a new concept and perspective in redox biology. FEBS Lett. 2018, 592, 2140-2152. [CrossRef]

3. Yadav, P.K.; Martinov, M.; Vitvitsky, V.; Seravalli, J.; Wedmann, R.; Filipovic, M.R.; Banerjee, R. Biosynthesis and reactivity of cysteine persulfides in signaling. J. Am. Chem. Soc. 2016, 138, 289-299. [CrossRef] [PubMed]

4. Kabil, O.; Yadav, V.; Banerjee, R. Heme-dependent metabolite switching regulates $\mathrm{H}_{2} \mathrm{~S}$ synthesis in response to endoplasmic reticulum (ER) stress. J. Biol. Chem. 2016, 291, 16418-16423. [CrossRef]

5. Kabil, O.; Banerjee, R. Enzymology of $\mathrm{H}_{2} \mathrm{~S}$ biogenesis, decay and signaling. Antioxid. Redox Sign. 2014, 20, 770-782. [CrossRef] [PubMed]

6. Walsh, B.J.C.; Giedroc, D.P. $\mathrm{H}_{2} \mathrm{~S}$ and reactive sulfur signaling at the host bacterial pathogen interface. J. Biol. Chem. 2020. [CrossRef] [PubMed]

7. Li, H.; Liu, H.; Chen, Z.; Zhao, R.; Wang, Q.; Ran, M.; Xia, Y.; Hu, X.; Liu, J.; Xian, M.; et al. Using resonance synchronous spectroscopy to characterize the reactivity and electrophilicity of biologically relevant sulfane sulfur. Redox Biol. 2019, 24. [CrossRef]

8. Ono, K.; Akaike, T.; Sawa, T.; Kumagai, Y.; Wink, D.A.; Tantillo, D.J.; Hobbs, A.J.; Nagy, P.; Xian, M.; Lin, J.; et al. Redox chemistry and chemical biology of $\mathrm{H}_{2} \mathrm{~S}$, hydropersulfides, and derived species: Implications of their possible biological activity and utility. Free Radic. Biol. Med. 2014, 77, 82-94. [CrossRef]

9. Kimura, H. Signaling molecules: Hydrogen sulfide and polysulfide. Antioxid. Redox Sign. 2015, 22, 362-376. [CrossRef]

10. Mishanina, T.V.; Libiad, M.; Banerjee, R. Biogenesis of reactive sulfur species for signaling by hydrogen sulfide oxidation pathways. Nat. Chem. Biol. 2015, 11, 457-464. [CrossRef]

11. Kimura, H. Signalling by hydrogen sulfide and polysulfides via protein S-sulfuration. Br. J. Pharmacol. 2019. [CrossRef] [PubMed]

12. Cortese-Krott, M.M.; Kuhnle, G.G.C.; Dyson, A.; Fernandez, B.O.; Grman, M.; DuMond, J.F.; Barrow, M.P.; McLeod, G.; Nakagawa, H.; Ondrias, K.; et al. Key bioactive reaction products of the $\mathrm{NO} / \mathrm{H}_{2} \mathrm{~S}$ interaction are S/N-hybrid species, polysulfides, and nitroxyl. Proc. Natl. Acad. Sci. USA. 2015, 112, E4651-E4660. [CrossRef] [PubMed]

13. Hu, X.; Li, H.; Zhang, X.; Chen, Z.; Zhao, R.; Hou, N.; Liu, J.; Xun, L.; Liu, H. Developing polysulfide-sensitive gfps for real-time analysis of polysulfides in live cells and subcellular organelles. Anal. Chem. 2019, 91, 3893-3901. [CrossRef] [PubMed]

14. Kim, J.A. Peroxisome Metabolism in cancer. Cells 2020, 9, 1692. [CrossRef] [PubMed]

15. Brady, N.R.; Hamacher-Brady, A.; Westerhoff, H.V.; Gottlieb, R.A. A wave of reactive oxygen species (ROS)-induced ROS release in a sea of excitable mitochondria. Antioxid. Redox Sign. 2006, 8, 1651-1665. [CrossRef]

16. Akaike, T.; Ida, T.; Wei, F.Y.; Nishida, M.; Kumagai, Y.; Alam, M.M.; Ihara, H.; Sawa, T.; Matsunaga, T.; Kasamatsu, S.; et al. Cysteinyl-tRNA synthetase governs cysteine polysulfidation and mitochondrial bioenergetics. Nat. Commun. 2017, 8. [CrossRef]

17. Hussain, S.; Malik, A.H.; Iyer, P.K. FRET-assisted selective detection of flavins via cationic conjugated polyelectrolyte under physiological conditions. J. Mater. Chem. B 2016, 4, 4439-4446. [CrossRef] 
18. Bergman, L.W. Growth and maintenance of yeast. Methods Mol. Biol. 2001, 177, 9-14. [CrossRef]

19. Xin, Y.; Liu, H.; Cui, F.; Liu, H.; Xun, L. Recombinant Escherichia coli with sulfide:quinone oxidoreductase and persulfide dioxygenase rapidly oxidises sulfide to sulfite and thiosulfate via a new pathway. Environ. Microbiol. 2016, 18, 5123-5136. [CrossRef]

20. Luebke, J.L.; Shen, J.; Bruce, K.E.; Kehl-Fie, T.E.; Peng, H.; Skaar, E.P.; Giedroc, D.P. The CsoR-like sulfurtransferase repressor (CstR) is a persulfide sensor in Staphylococcus aureus. Mol. Microbiol. 2014, 94, 1343-1360. [CrossRef]

21. Xia, Y.; Chu, W.; Qi, Q.; Xun, L. New insights into the QuikChange ${ }^{\mathrm{TM}}$ process guide the use of Phusion DNA polymerase for site-directed mutagenesis. Nucl. Acids Res. 2015, 43, e12. [CrossRef]

22. Li, H.; Li, J.; Lü, C.; Xia, Y.; Xin, Y.; Liu, H.; Xun, L.; Liu, H. FisR activates $\sigma^{54}$-dependent transcription of sulfide-oxidizing genes in Cupriavidus pinatubonensis JMP134. Mol. Microbiol. 2017, 105, 373-384. [CrossRef]

23. Bošnjak, I.; Bojović, V.; Šegvić-Bubić, T.S.; Bielen, A. Occurrence of protein disulfide bonds in different domains of life: A comparison of proteins from the Protein Data Bank. Protein Eng. Des. Sel. 2014, 27, 65-72. [CrossRef] [PubMed]

24. Merzlyak, E.M.; Goedhart, J.; Shcherbo, D.; Bulina, M.E.; Shcheglov, A.S.; Fradkov, A.F.; Gaintzeva, A.; Lukyanov, K.A.; Lukyanov, S.; Gadella, T.W.J.; et al. Bright monomeric red fluorescent protein with an extended fluorescence lifetime. Nat. Methods 2007, 4, 555-557. [CrossRef] [PubMed]

25. Shaner, N.C.; Campbell, R.E.; Steinbach, P.A.; Giepmans, B.N.G.; Palmer, A.E.; Tsien, R.Y. Improved monomeric red, orange and yellow fluorescent proteins derived from Discosoma sp. red fluorescent protein. Nat. Biotechnol. 2004, 22, 1567-1572. [CrossRef] [PubMed]

26. Han, Q.; Mou, Z.; Wang, H.; Tang, X.; Dong, Z.; Wang, L.; Dong, X.; Liu, W. Highly selective and sensitive oneand two-photon ratiometric fluorescent probe for intracellular hydrogen polysulfide sensing. Anal. Chem. 2016, 88, 7206-7212. [CrossRef] [PubMed]

27. Chen, W.; Liu, C.; Peng, B.; Zhao, Y.; Pacheco, A.; Xian, M. New fluorescent probes for sulfane sulfurs and the application in bioimaging. Chem. Sci. 2013, 4, 2892-2896. [CrossRef]

28. Umezawa, K.; Kamiya, M.; Urano, Y. A reversible fluorescent probe for real-time live-cell imaging and quantification of endogenous hydropolysulfides. Angew. Chem. Int. Ed. Engl. 2018, 57, 9346-9350. [CrossRef]

29. Takano, Y.; Hanaoka, K.; Shimamoto, K.; Miyamotoet, R.; Komatsu, T.; Ueno, T.; Terai, T.; Kimura, H.; Nagano, T.; Urano, Y. Development of a reversible fluorescent probe for reactive sulfur species, sulfane sulfur, and its biological application. Chem. Commun. 2017, 53, 1064-1067. [CrossRef]

30. Gao, M.; Wang, R.; Yu, F.; You, J.; Chen, L. Imaging and evaluation of sulfane sulfur in acute brain ischemia using a mitochondria-targeted near-infrared fluorescent probe. J. Mater. Chem. B. 2018, 6, 2608-2619. [CrossRef]

31. Han, X.; Song, X.; Li, B.; Yu, F.; Chen, L. A near-infrared fluorescent probe for sensitive detection and imaging of sulfane sulfur in living cells and in vivo. Biomater. Sci. 2018, 6, 672-682. [CrossRef] 